\title{
High Resolution Mass Spectrometry Analysis of the Sertraline Residues Contained in the Tissues of Rainbow Trout Reared in Model Experimental Conditions
}

\author{
Josef VACLAVIK ${ }^{1}$, Pavla SEHONOVA ${ }^{1}$, Denisa MEDKOVA ${ }^{1,2}$, Kamil STASTNY ${ }^{3}$, Michaela \\ CHARVATOVA ${ }^{3}$, Martin FALDYNA ${ }^{3}$, Jan MARES ${ }^{2}$, Zdenka SVOBODOVA ${ }^{1}$ \\ ${ }^{1}$ Department of Animal Protection and Welfare \& Veterinary Public Health, Faculty of Veterinary \\ Hygiene and Ecology, University of Veterinary and Pharmaceutical Sciences Brno, Czech \\ Republic, ${ }^{2}$ Department of Zoology, Fisheries, Hydrobiology and Apiculture, Faculty of \\ Agrisciences, Mendel University in Brno, Czech Republic, ${ }^{3}$ Veterinary Research Institute, \\ Department of Infectious Diseases and Preventive Medicine, Brno, Czech Republic
}

Received October 8, 2020

Accepted October 24, 2020

\section{Summary}

The growing consumption of pharmaceuticals in the human population and the insufficient efficiency of their elimination in waste water has a long-term negative impact on the environment of aquatic ecosystems, including the organisms that inhabit them. A significant contributor is the consumption of antidepressants from the SSRI group, which corresponds to their increasing concentration in the environment. The aim of this work was to determine if antidepressant sertraline is able to be stored in fish organisms and to evaluate the content of residues in various body tissues. Rainbow trout (Oncorhynchuss mykkis) was selected as the test organism and was artificially exposed to the antidepressant for 1 month (concentrations $0 ; 4.2 ; 44$ and $400 \mathrm{ng} . \mathrm{g}^{-1}$ sertraline in the feed). Liver, kidney, brain and muscle tissue biopsies samples were taken for analysis. Detection was performed using an Accela 1250 LC pump and an Accela autosampler coupled with a high-performance mass analyzer with a heated electrospray ionization source Q-Exactive Orbitrap, operating in positive ionization mode and in PRM mode $(\mathrm{m} / \mathrm{z} \quad 306.08108 \rightarrow 275.03888$ and $309.009991 \rightarrow 275.03888$ for sertraline and internal standard, respectively). The limit of quantification of the method was $0.1 \mathrm{ng} . \mathrm{g}^{-1}$ of sertraline and the calibration curve showed a good linearity up to $20 \mathrm{ng} \cdot \mathrm{g}^{-1}$. From the collected data, amount of residues was found in the liver, kidney and brain. In contrast, the incidence of residues in muscle tissue was not detected in all groups, which is favorable from the point of view of fish meat consumption, by humans.

\section{Key words}

Antidepressant • Oncorhynchus mykkis • Water environment • Brain

\section{Corresponding author}

J. Vaclavik, Department of Animal Protection and Welfare \& Veterinary Public Health, Faculty of Veterinary Hygiene and Ecology, University of Veterinary and Pharmaceutical Sciences Brno, Palackého tř́́da 1, 612 42, Brno, Czech Republic. E-mail: H17014@vfu.cz

\section{Introduction}

The water environment is burdened by an increasing amount of residues from human medicine. Due to the current trend to deal with stressful situations by medicament treatment, a load of metabolites from the field of antidepressants is increasing. An important group of these substances are SSRIs - selective serotonin reuptake inhibitors, including sertraline (SER), the main active substance in Zoloft - medicament usual used for the treatment anxiety, depression and panic mood. Currently, the system of sertraline waste products elimination is not perfect (removal efficiency around $90 \%$ - Gornik et al. 2020), part of sertraline residues gradually enters through wastewater treatment plants into the water effluent, including surface water, where sertraline gets accumulated in sediment and enters the

PHYSIOLOGICAL RESEARCH • ISSN 1802-9973 (online) 
food chain from invertebrates to fish. Long-term exposure to waste products can represent a significant burden for aquatic organisms, which is manifested by various chronic negative effects such as behavior, biochemical and immunity changes (Xie et al. 2015, Vaclavik et al. 2020).

Various published studies describe occurrence of this substance in the water environment. Rezka et al. (2016) found the concentration of sertraline from the samples of sediment at the outflow of wastewater treatment plants in the range from 203 up to $528 \mathrm{ng}^{-\mathrm{g}^{-1}}$. Grabicova et al. (2017) measured the average value of soluble SER in water at the flow of Zivny potok to be 2.4 ng..$^{-1}$.

Based on the available literature (Brooks et al. 2005, Grabicova et al. 2017), the dominant place of antidepressant storage in fish as all vertebrates are the liver, where SER is primarily metabolized, and brain tissue, place of target activity. From the point of consumers view, the potential of residues accumulation in muscle tissue may be interesting, especially fish species destined for the food industry. Grabicova et al. (2017) described the occurrence of sertraline in individual tissues of rainbow trout (Oncorhynchus mykkis) - liver 24 ng. $\mathrm{g}^{-1}$, brain tissue $15 \mathrm{ng} \cdot \mathrm{g}^{-1}$, kidneys $48 \mathrm{ng} \cdot \mathrm{g}^{-1}$. Also Brooks et al. (2005) analyzed samples of three fish species including great sunflower (Lepomis macrochirus), the spotted catfish (Ictalurus punctatus) and the blackspotted perch (Pomoxis nigromaculatus) captured at Pecan Creek with an average antidepressant value in

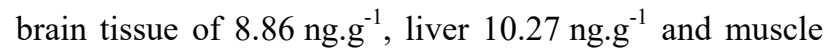
1.07 ng. $\mathrm{g}^{-1}$.

This work aimed to evaluate the deposition potential of the antidepressant SER in individual tissues of rainbow trout (liver, kidney, muscle and brain tissue), which was exposed to the feed contained SER under the experimental conditions (the low tested concentration corresponded to the concentration occurring in the environment). From previous studies, we expected the highest concentrations in liver and brain tissues (Grabicova et al. 2017), the place of antidepressant metabolisation, and low incidence of sertraline in muscle (Brooks et al. 2005). For determination, the high resolution mass spectrometry analysis was used.

\section{Methods}

\section{Test design}

A 28-day growth toxicity test according to
OECD 215 was performed on juvenile rainbow trout (Oncorhynchus mykkis). At the start of the experiment, the fish were divided into 8 tanks (1 group included 10 fish). The control group (performed in duplicate) and three testing groups with ascending concentrations of sertraline $4.4 \mu \mathrm{g} \cdot \mathrm{kg}^{-1}$ (low), $42 \mu \mathrm{g} . \mathrm{kg}^{-1}$ (medium), and $400 \mu \mathrm{g} . \mathrm{kg}^{-1}$ (high) were tested. The testing doses were based on the concentration values found in benthos (Grabicova et al. 2017). The test substance SER was administered to the fish twice a day incorporated into Biomar 920 feed. The preparation of the feed pellets was carried out by the method analogous to the dust coating (SER was dissolved in the acrylic polymer). At the end of the experiment, the fish were killed and 10 samples of kidney, liver and muscle, 5 samples of brain from each concentration including control were taken for determination of SER residues. Material and methods used in the experiment were described in detail by Vaclavik et al. (2020).

\section{Determination of residues}

\section{Materials and reagents}

Sertraline hydrochloride CRS and isotopelabelled $( \pm$ )-sertraline-D3 hydrochloride (purity $\leq 99 \%$ ) were obtained from Sigma Aldrich (Germany). Acetonitrile and methanol both hypergrade for LC/MS and formic acids for acidification were also purchased from Sigma Aldrich (Germany). Ultrapure water was prepared using Goldman GW instrument (Czech Republic).

\section{Calibration standards and quality control samples}

Stock solutions of SER $\left(1 \mathrm{mg} \cdot \mathrm{ml}^{-1}\right)$ and sertraline-D3 $\left(100 \mu \mathrm{g} \cdot \mathrm{ml}^{-1}\right)$ were prepared in methanol and stored at $-20^{\circ} \mathrm{C}$ until use. Working solutions of SER $\left(100 \mu \mathrm{g} \cdot \mathrm{ml}^{-1}\right)$ for calibration standards (concentration levels in the range of $0.1-20 \mathrm{ng}^{-\mathrm{g}^{-1}}$ ) and

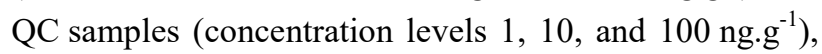
as well as IS working solution $\left(1 \mu \mathrm{g} . \mathrm{ml}^{-1}\right)$ were prepared by further dilution of aliquots of stock solutions with methanol. The solutions were stable at least for 1 month at $4{ }^{\circ} \mathrm{C}$.

\section{Sample preparation}

Extracts from fish tissues were prepared according to Fedorova et al. (2014), with a slight modification. Briefly, the muscle, liver, kidney and brain samples were cut into small pieces, $0.5 \mathrm{~g}$ of muscle and 
$0.25 \mathrm{~g}$ of liver, kidney and brain were weighted to Eppendorf-tube, and $10 \mathrm{ng}$ of internal standard (final

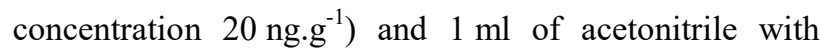
$0.1 \%$ formic acid ( $5 \mathrm{ng}$ of IS and $0.5 \mathrm{ml}$ of acetonitrile with $0.1 \%$ formic acid, respectively) was added. Samples were extracted in multi speed vortex (Grant-Bio, Multi Speed Vortex MSV - 3500) for $15 \mathrm{~min}$ at $3000 \mathrm{rpm}$. Extracts were centrifuged for $15 \mathrm{~min}$ at $14500 \mathrm{rpm}$ (Eppendorf, Mini Spin plus), and than supernatant solutions were frozen at $-20^{\circ} \mathrm{C}$ for $30 \mathrm{~min}$. Later, supernatants were centrifuged for $15 \mathrm{~min}$ at $14000 \mathrm{rpm}$ at $4{ }^{\circ} \mathrm{C}$ (Eppendorf, centrifuge $5804 \mathrm{R}$ ). Supernatants were filtered through $0.45 \mu \mathrm{m}$ PTFE centrifuge filter (Thermo Scientific) and filtrates were evaporated to dryness under gentle nitrogen stream at $30^{\circ} \mathrm{C}$ (ECOM, Termovap TV 10+) and residues were reconstituted with $200 \mu$ of methanol and kept in the freezer at $-20{ }^{\circ} \mathrm{C}$ until analysis.

\section{HPLC-ESI-MS/MS analysis}

Analysis was performed using an Accela 1250 LC pump and an Accela autosampler coupled with a high-performance mass analyzer with a heated electrospray ionization source Q Exactive Orbitrap all from Thermo Fisher Scientific (USA).

Analyte separation was performed on Luna $\mathbb{R}$ C18 column $(100 \mathrm{~mm} \times 2.1 \mathrm{~mm}, 1.6 \mu \mathrm{m})$ and UHPLC C18 guard column $(10 \mathrm{~mm} \times 2.1 \mathrm{~mm}, 3 \mu \mathrm{m}$ particle size $)$, both from Phenomenex ${ }^{\circledR}$ (USA). Methanol - $5 \%$ (A) and $95 \%$ methanol (B) were used as mobile phase, both containing $0.1 \% \mathrm{HCOOH}$. Column flow was set at $0.25 \mathrm{ml} \cdot \mathrm{min}^{-1}$ and column temperature was maintained at $40{ }^{\circ} \mathrm{C}$. Gradient elution started with $100 \% \mathrm{~A}$ and kept for $0.5 \mathrm{~min}$ and that changed to $100 \% \mathrm{~B}$ in $3 \mathrm{~min}$, then kept $100 \% \mathrm{~B}$ for $4 \mathrm{~min}$. Then, the mobile phase composition was changed to starting condition in 8 min and kept for 2 min.

External calibration of the q-Orbitrap mass analyzer was performed every three days using Pierce LTQ ESI (Thermo Fisher Scientific) calibration solutions. Measurements were performed in positive ionization in PRM mode at 17.500 FWHM with an isolation window of $0.8 \mathrm{~m} / \mathrm{z}$ with a normalized collision energy (NCE) of 35. ACG target was set at $2 \mathrm{e}^{5}$. With respect to the HESI parameters, spray voltage was set at $4.5 \mathrm{kV}$ for, the capillary temperature was set at $320^{\circ} \mathrm{C}$, the sheath gas at 5 arbitrary units (au), the auxiliary gas at $1 \mathrm{au}$.

Xcalibur 3.1 (Thermo Fischer Scientific) was used for instrument control. Quantitative determination was performed in PRM scan mode using the following transitions: $\mathrm{m} / \mathrm{z} 306.08108 \rightarrow 275.03888$ for sertraline and IS, respectively. $5 \mathrm{ppm}$ mass error was accepted for fragment ions.

\section{Method validation}

The method was validated for parameters such as linearity, limit of detection (LOD), limit of quantification (LOQ), recovery and intra- and inter-day precisions. The method validation followed the VICH-GL2 and VICH-GL49 recommendations. Linearity of method was confirmed by using the peak area ratio of analyte to internal standard versus the concentration of analyte. Matrix-matched (muscle tissue) calibration

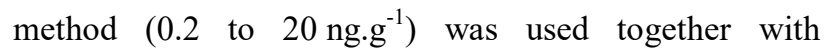
isotopically labelled standard $\left(20 \mathrm{ng}^{-\mathrm{g}^{-1}}\right)$ in order to correct the matrix effects. Calibration standards were measured at the beginning and at the end of each sequence. Solvent blanks containing methanol were measured repeatedly throughout the sequence every five samples for monitoring the instrumental background. LOD and LO) were obtained on the basis of signal to noise $(\mathrm{S} / \mathrm{N})$ ratio of 3 and 10 , respectively. Recovery was measured as the difference between the spiked concentration and the measured concentration and expressed as a percentage of the spiked value. The recovery measurements on concentration level $10 \mathrm{ng} \cdot \mathrm{g}^{-1}$ were performed on all four tissue types, i.e. muscle, liver, kidney and brain. Intra- and inter-day precisions were expressed as the relative standard deviation (RSD) of the six identical muscle samples at each concentration of 1 , 10 , and $100 \mathrm{ng} \cdot \mathrm{g}^{-1}$ of sertraline (inter-day precision was analyzed on three separate days).

\section{Ethical statement}

Experimental steps were in compliance with national legislation - Act No. 246/1992 Coll., on the Protection of Animals against Cruelty, as amended and Decree No. 419/2012 Coll., on the Protection, Breeding and use of Experimental Animals, as amended.

\section{Results}

Mass spectra of sertraline and HPLC - ESI-MS / MS analysis

Full-scan mass spectrum of sertraline is reported in Figure 1. The molecular ion of sertraline corresponds to $\mathrm{m} / \mathrm{z} 306.08108$ (309.09991 for sertraline-D3) and from it fragmentation produces the main product ions 
275.03888 and 158.97628. This two most intense peaks in the product ion mass spectra were chosen for the quantification of the analyte and the internal standard.

Selectivity is demonstrated by the chromato- grams of blank and spiked muscle samples shown in Figure 2. No endogenous interference peaks were apparent at $5.3 \mathrm{~min}$, the retention time of sertraline and sertraline-D3, respectively.

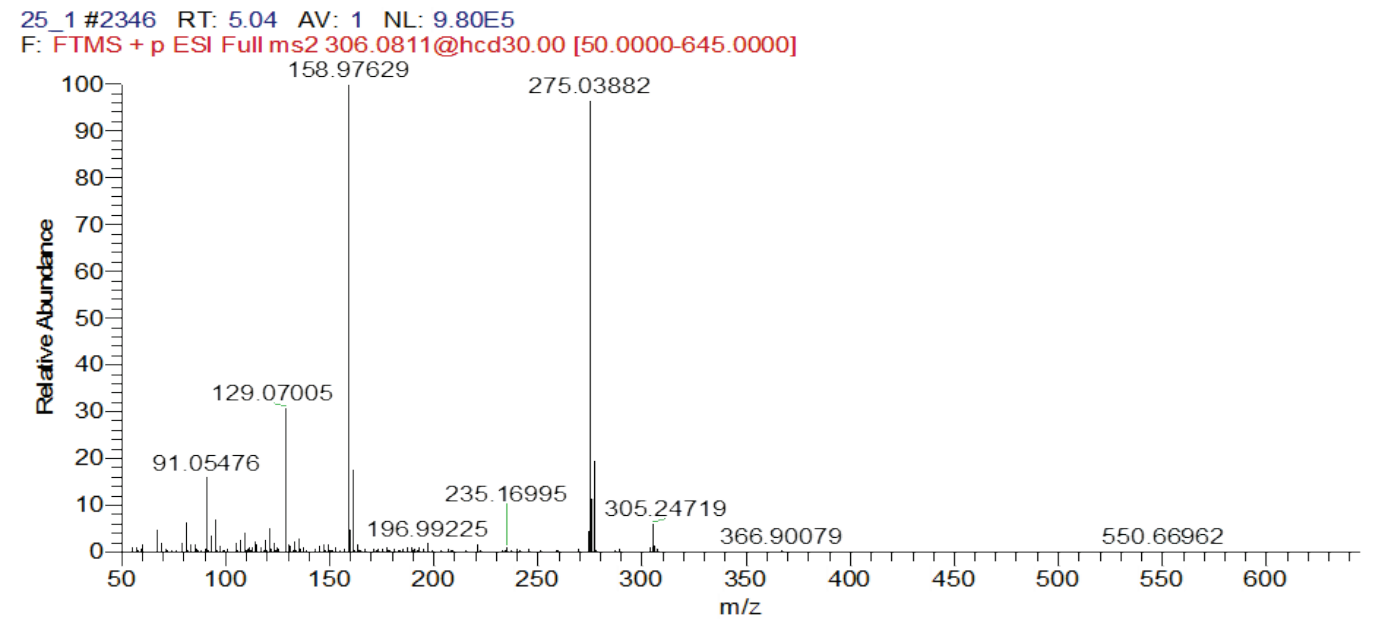

Fig. 1. Sertraline mass spectrum.
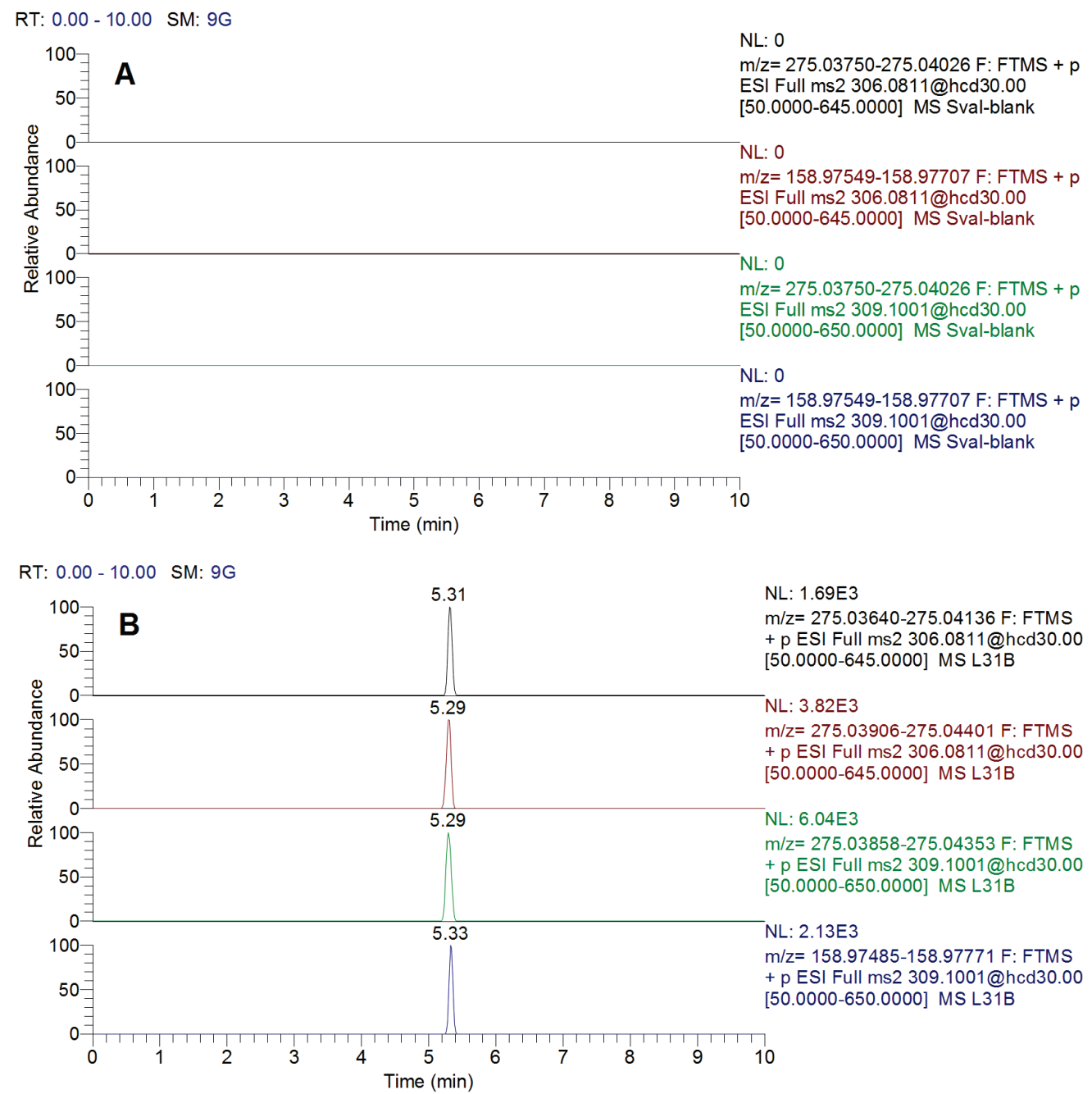

Fig. 2. Chromatogram with sertraline content below the LOD of the method $(\mathbf{A})$ and chromatogram spiked with $10 \mathrm{ng} \cdot \mathrm{g}^{-1}$ sertraline and $20 \mathrm{ng}^{-\mathrm{g}^{-1}}$ sertraline-D3 (B). 


\section{Validation}

Validation of methods for the determination of sertraline should be carried out according to VICH-GL2 and VICH-GL49 recommendations.

The evaluation of the linear response was performed on matrix-matched calibration with seven concentration levels ranging from 0.2 to $20{\mathrm{ng} . \mathrm{g}^{-1}}^{-1}$ (calibration points $0.2 ; 0.5 ; 1 ; 2 ; 5 ; 10 ; 20$ ). The concentration range was chosen taking into account the predicted sertraline content of the tissues. Sertraline showed very good linearity $\left(r^{2}>0.998\right)$ through the entire tested concentration range. Determination of limit of detection and limit of quantification are based on signal to noise $(\mathrm{S} / \mathrm{N})$ ratio. The LOD was calculated as $0.05 \mathrm{ng} . \mathrm{g}^{-1}$ and the LOQ as $0.1 \mathrm{ng} \cdot \mathrm{g}^{-1}$.

Method accuracy expressed as recovery (\%) was tested for muscle, kidney, liver and brain tissue. Samples were fortified at concentration $10 \mathrm{ng}^{\mathrm{g}} \mathrm{g}^{-1}$ and three replicates were prepared from each tissue. Results are reported in Table 1.

Method precision (intra-day) was determined by performing six consecutive assays in the same day on QC samples spiked at three different sertraline concentration levels, i.e. 1.0 (low level), 10 (medium level), which are within the range of the calibration curve and $100 \mathrm{ng}^{-1} \mathrm{~g}^{-1}$ (over-range level). The QC samples were also analyzed in three different days to assess the interday precision (reproducibility) of the method. Due to a lack of brain, kidney and liver samples, these determinations were made only on muscle samples. The results are shown in Table 2.

Table 1. Recoveries for sertraline in different tissues. Samples were fortified at concentration $10 \mathrm{ng} \cdot \mathrm{g}^{-1}$.

\begin{tabular}{lcc}
\hline Tissue & Recovery (\%) & RSD (\%) \\
\hline Muscle & 101.5 & 4.7 \\
Liver & 84.1 & 6.2 \\
Kidney & 80.6 & 6.9 \\
Brain & 83.3 & 5.0 \\
\hline
\end{tabular}

Table 2. Intra- and inter-day precision of the method.

\begin{tabular}{lcc}
\hline Theoretical concentration (ng.g $\left.{ }^{-1}\right)$ & Mean back-calculated concentration (ng.g $\left.{ }^{-1}\right)$ & RSD (\%) \\
\hline Intra-day & & 7.5 \\
\hline 1 & 1.08 & 4.7 \\
10 & 10.15 & 3.3 \\
\hline $100^{a}$ & 100.4 & 6.9 \\
\hline Inter-day & & 6.3 \\
1 & 1.12 & 4.6 \\
\hline 10 & 9.86 & \\
\hline
\end{tabular}

a Over-range samples were diluted 1:10 with methanol before analysis.

\section{Residues data}

The results showed no occurrence of sertraline residues in all muscle samples. The tissues from the control and low testing groups were without contamination. In medium testing group, the occurrence of sertraline was detected only in the liver and kidney samples with highest

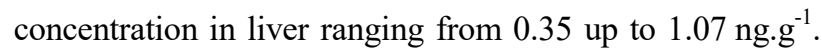
The content of residues in kidney was in the range
$0.28-0.43 \mathrm{ng} \cdot \mathrm{g}^{-1}$. The liver was also the most contaminated tissue from high testing group with average value of

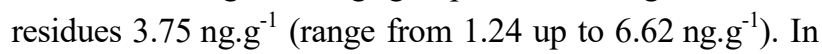
kidney was sertraline found in the range $1.24-4.62 \mathrm{ng}^{-\mathrm{g}^{-1}}$ with average value $2.32 \mathrm{ng} . \mathrm{g}^{-1}$ and in brain $0.27-0.57 \mathrm{ng} . \mathrm{g}^{-1}$ (average value $0.35 \mathrm{ng} \cdot \mathrm{g}^{-1}$ ). The measured values of residues are reported in Table 3. 
Table 3. Content of sertraline residues in individual groups (mean $\pm \mathrm{SEM}, \mathrm{ng} \cdot \mathrm{g}^{-1}$ ).

\begin{tabular}{lcccc}
\hline Type of tissue & Control & Low & Medium & High \\
\hline Liver & ND & ND & $0.54 \pm 0.08$ & $3.75 \pm 0.54$ \\
Kidney & ND & ND & $0.39 \pm 0.03$ & $2.32 \pm 0.37$ \\
Brain & ND & ND & ND & $0.35 \pm 0.16$ \\
Muscle & ND & ND & ND & ND \\
\hline
\end{tabular}

\section{Discussion}

Based on the validation parameters listed selective and sensitive method using HPLC with detection by MS-MS for the determination of sertraline in rainbow trout tissues was developed. The achieved LOQ corresponds to LOQs published by other authors (Wang, 2012, Grabicova et al. 2018). Determined recovery at a level of $10 \mathrm{ng} \cdot \mathrm{g}^{-1}$ for muscle, liver, kidney and brain tissue were identical to the results published by Grabicova et al. (2018).

From the collected data we confirmed that the main tissues in fish where sertraline is primarily stored are liver and kidney, with the highest measured concentration $6.62 \mathrm{ng} . \mathrm{g}^{-1}$ for liver respectively $4.62 \mathrm{ng} . \mathrm{g}^{-1}$ for kidney (corresponding with a study published by Brooks et al. 2005, Grabicova et al. 2017). In contrast with this, the presence of antidepressant in muscle was not detectable in all testing groups what is positive for fish consumers. Also Brooks et al. (2005) described low concentration of antidepressants in muscle which rejects a theory that sertraline as a lipophilic substance has higher bioconcentration affinity for tissues with higher fat content (Nowakowska et al. 2020).

Measured values are lower compared to other published articles (Grabicova et al. 2014, Grabicova et al.
2017), which can be due to the test methodology, when in this experiment were fish artificially exposed to an antidepressant for only 4 weeks, while other experiments were based on catching fish from the natural environment, where are fish naturally exposed this substance for a long time, which may represent a higher potential for the sertraline accumulation in individual body tissues.

In general, various previous studies described that antidepressant have long term effect on fish organism. Due to the fact that medicament consumption including antidepressants in the world is constantly increasing, it is important to continuously study and monitor the negative influence of these substances such as sertraline and others.

\section{Conflict of Interest}

There is no conflict of interest.

\section{Acknowledgements}

This work was funded by the project IGA University of Veterinary and Pharmaceuticals Sciences Brno (Czech Republic) $211 / 2018 /$ FVHE and by the ERDF/ESF "Profish" [No. CZ.02.1.01/0.0/0.0/16_019/0000869, Czech Republic].

\section{References}

BROOKS BW, CHAMBLISS CK, STANLEY JK, RAMIREZ A, BANKS KE, JOHNSONS RD, LEWIS RJ: Determination of select antidepressants in fish from an effluent dominated stream. Environ Toxicol 24: 464-469, 2005. https://doi.org/10.1897/04-081R.1

FEDOROVA G, NEBESKY V, RANDAK T, GRABIC R: Simultaneous determination of 32 antibiotics in aquaculture products using LC-MS/MS. Chem Paper 68: 29-36, 2014. https://doi.org/10.2478/s11696-013-0428-3

GRABICOVA K, LINDBERG RH, ÖSTMAN M, GRABIC R, RANDAK T, LARSSON DGJ, FICK J: Tissue-specific bioconcentration of antidepressants in fish exposed to effluent from a municipal sewage treatment plant. Sci Total Environ 488-489: 46-50, 2014. https://doi.org/10.1016/j.scitotenv.2014.04.052

GRABICOVA K, GRABIC R, FEDOROVA G, FICK J, CERVENY D, KOLAROVA J, TUREK J, ZLABEK V, RANDAK T: Bioaccumulation of psychoactive pharmaceuticals in fish in an effluent dominated stream. Water Res 124: 654-662, 2017. https://doi.org/10.1016/j.watres.2017.08.018 
GRABICOVA K, STANOVA AV, TUN OK, BORIK A, RANDAK T, GRABIC R: Development of a robust extraction procedure for the HPLC-ESI-HRPS determination of multi-residual pharmaceuticals in biota samples. Anal Chim Acta 1022: 53-60, 2018. https://doi.org/10.1016/j.aca.2018.04.011

GRABICOVA K, GRABIC R, BLAHA M, KUMAR V, CERVENY D, FEDOROVA G, RANDAK T: Presence of pharmaceuticals in benthic fauna living in a small stream affected by effluent from a municipal sewage treatment plant. Water Res 72: 145-153, 2015. https://doi.org/10.1016/j.watres.2014.09.018

GORNIK T, KOVACIC A, HEATH E, HOLLENDER J, KOSJEK T: Biotransformation study of antidepressant sertraline and its removal during biological wastewater treatment. Water Res 181: 115864, 2020. https://doi.org/10.1016/j.watres.2020.115864

NOWAKOWSKA K, GIEBULTOWICZ J, KAMASZEWSKI M, ADAMSKI M, SZUDROWICZ H, OSTASZEWSKA T, SOLARSKA-DZIECIOLOWSKA U, NALECZ-JAWECKI G, WROCZYNSKI P, DROBNIEWSKA A: Acute exposure of zebrafish (Danio rerio) larvae to environmental concentrations of selected antidepressants: Bioaccumulation, physiological and histological changes. Comp Biochem Physiol C Toxicol Pharmacol 229: 108670, 2020. https://doi.org/10.1016/j.cbpc.2019.108670

REZKA P, BALCERZAK W: Occurrence of antidepressants - from wastewater to drinking water. Tech Trans 146 : 486-496, 2016.

VACLAVIK J, SEHONOVA P, HODKOVICOVA N, VECERKOVA L, BLAHOVA J, FRANC A, MARSALEK P, MARES J, TICHY F, SVOBODOVA Z, FAGGIO C: Effect of foodborne sertraline on rainbow trout (Oncorhynchus mykiss). Sci Total Environ 708: 135082, 2020. https://doi.org/10.1016/j.scitotenv.2019.135082

VICH-GL2 Validation of analytical procedures: methodology, European Medicines Agency, http://www.ema.europa.eu, 2015.

VICH-GL49 Studies to evaluate the metabolism and residue kinetics of veterinary drugs in food-producing animals: validation of analytical methods used in residue depletion studies. European Medicines Agency, http://www.ema.europa.eu, 2015.

WANG J, GARDINALI PR: Analysis of selected pharmaceuticals in fish and the fresh water bodies directly affected by reclaimed water using liquid chromatography-tandem mass spectrometry. Anal Bioanal Chem 404: 2711-2720, 2012. https://doi.org/10.1007/s00216-012-6139-8

XIE Z, LU G, LI S, NIE Y, MA B, LIU J: Behavioral and biochemical responses in freshwater fish Carassius auratus exposed to sertraline. Chem 135: 146-155, 2015. https://doi.org/10.1016/j.chemosphere.2015.04.031 